\title{
Potensi Kuantitatif dan Kualitatif 10 Galur Unggul Baru Padi Jenis Pandan Wangi
}

\section{Potential Quantitative and Qualitative 10 Superior New Strain of Rice Pandan Wangi}

\author{
Jaenudin Kartahadimaja ${ }^{1}$, Eka Erlinda Syuriani ${ }^{1}$, dan Marlinda Apriyani ${ }^{2}$ \\ ${ }^{1}$ Dosen Program Studi Teknologi Perbenihan Jurusan Budidaya Tanaman Pangan Polinela \\ ${ }^{2}$ Dosen Agribisnis Jurusan Ekonomi dan Bisnis Polinela \\ Jl. Soekarno- Hatta, No.10 Rajabasa, Bandar Lampung, Tlp. 0721703995 \\ Email: jaenudinkartahadimaja@gmail.com
}

\begin{abstract}
Rice is a staple food that is very dominant for Indonesia. Production of rice in 2014 as many as 70,85 million tons of milled rice, 0,61\% lower than production in 2013. One way to increase production is the use of high yielding varieties. Polinela have to assemble ten new rice lines Pandan wangi species which have superior appearance. The research goal is to test the potential yield and quality of rice ten new rice strains. The study was conducted in Polinela for 6 months. The study was conducted using Randomized Completely Block Design ( RCBD ).The treatment consisted of ten strains of rice, is repeated three times. The variables measured were (1) dry milled grain yield per hectare; (2) the levels of amylose and amylopectin. Qualitative variables measured were the texture and the smell of ricewith organoleptic method. Quantitative data were analyzed by analysis of variance, if there is a difference between the treatment continued with Test Honestly Significant Difference (HSD) on the real level of 0.05. Heritability of quantitative variables were observed calculated to estimate whether the variable-variable controlled bygenetic factors or environment?The results showed the new rice lines Polinela assemblies have a range of potential outcomes of milled rice ( $G K G$ ) between 6.47 to 9.79 tonnes/ha,amylose content is low to moderate, very fluffier texture until fluffier rice.
\end{abstract}

Keywords: yield potential, new rice strains

Diterima: 01 Februari 2016, disetujui 20 April 2016

\section{PENDAHULUAN}

Bagi bangsa Indonesia, beras merupakan pangan pokok yang sangat dominan. Kelangkaan penyediaan beras menyebabkan melonjaknya harga beras yang berdampak baik secara langsung maupun tidak langsung dapat memperparah krisis ekonomi, sosial, dan politik (Suryana dkk., 2009).

Produksi padi tahun 2014 sebanyak 70,85 juta ton gabah kering giling (GKG), mengalami penurunan sebanyak 0,43 juta ton (0,61\%) dibanding tahun 2013 (Badan Pusat Statistik, 2015). Produksi beras dapat dipacu melalui peningkatan luas tanam dan penggunaan varietas yang memiliki produktivitas tinggi. Peningkatan potensi hasil suatu tanaman padi dapat dilakukan dengan memodifikasi arsitektur tan tanaman melalui pemuliaan tanaman dan seleksi (Abdullah, 2009).

Jenis dan kualitas padi yang dikembangkan di masyarakat bervariasi, mulai dari yang berkualitas rendah sampai berkualitas tinggi (baik). Beras kualitas rendah dicirikan dengan warna 
yang putih kotor, butiran beras banyak yang patah, tekstur nasi yang keras atau pera, aroma yang tidak harum bahkan ada yang bau apek. Beras berkualitas baik memiliki karakter butiran beras agak besar dan seragam, butiran beras tidak patah, warna beras putih cerah, tekstur nasi yang lunak atau pulen, memiliki aroma yang harum atau wangi.

Politeknik Negeri Lampung (Polinela) sedang mengembangkan padi jenis Pandan Wangi. Perakitaan dilakukan dengan teknik pemuliaan konvensional. Plasma nutfah yang digunakan sebagai tetua persilangan berasal dari beberapa varietas unggul nasional yang memilki keragaman genetik yang berbeda disilangkan dengan jenis padi pandan wangi yang memiliki potensi hasil tinggi, kualitas beras baik dengan aroma nasi yang wangi. Zuriat hasil persilangan mulai generasi ke-2 $\left(\mathrm{F}_{2}\right)$ diseleksi dengan metode pedigre, saat ini telah dihasilkan 10 galur harapan generasi ke- $8\left(\mathrm{~F}_{8}\right)$ yang memiliki penampilan superior (Kartahadimaja dan Syuriani, 2014). Galur-galur harapan tersebut menunjukkan karakter agronomi yang unggul, seperti tinggi tanaman rata-rata pendek, batang kekar, bentuk gabah agak besar, malai panjang, dan jumlah gabah tiap malai berkisar antara 150 - 250 butir. Tujuan Penelitian adalah menguji potensi hasil dan kualitas beras sepuluh galur padi baru rakitan Polinela.

\section{METODE}

Penelitian dilakukan di Politeknik Negeri Lampung (Polinela) selama 6 bulan. Penelitian dilakukan dengan menggunakan Rancangan Kelompok Teracak Sempurna (RKTS). Sebagai perlakuan adalah 10 galur padi, setiap perlakuan diulang tiga kali. Variabel yang diamati pada penelitian ini adalah (1) hasil gabah kering giling tiap hektar; (2) kadar amilosa dan amilopektin. Analisis kadar amilosa dan amilopektin dilakukan dengan metode spektrofotometri, sedangkan pengamatan rasa, tekstur dan aroma nasi dilakukan uji organoleptik dengan menggunakan 15 orang panelis.

Data dianalisis dengan sidik ragam, jika terdapat perbedaan diantara perlakuan dilanjutkan dengan Uji Beda Nyata Jujur (BNJ) pada taraf nyata 0,05. Untuk menduga apakah variabel -variabel yang diamati itu dikendalikan oleh faktor genetik atau lingkungan maka dari setiap nilai variabel yang dihasilkan, dihitung nilai heritabilitasnya.

\section{HASIL DAN PEMBAHASAN}

Potensi hasil gabah kering giling (GKG) ke 10 galur padi baru rakitan polinela bervariasi, yaitu berkisar antara 6,47- 9,79 ton/ha (Tabel 1). Galur E nyata lebih tinggi dari galur C, D, H, dan J. Berdasarkan potensi hasil yang dimiliki oleh galur padi baru di atas, peluang untuk dikembangkan menjadi calon varietas komersial sangat besar. Untuk mengetahui stabilitas hasil dan penampilan karakter unggul yang lain yang dimiliki oleh masing-masing galur, maka perlu dilanjutkan dengan uji multilokasi-multitahun.

Kadar amilosa merupakan salah satu sifat fisikokimia beras yang ditentukan oleh sifat pati yang berantai lurus. Kadar amilosa tekstur nasi $0-10 \%$ termasuk ketan, tekstur nasi dengan kandungan amilose 10-20\% termasuk katagori kandungan amilosa rendah dengan tekstur nasi sangat pulen, kandungan amilosa antara 20-25\% termasuk kandungan amilosa sedang, dengan tekstur nasi yang pulen. Kandungan amilosa $>25 \%$ termasuk katagori kandungan amilosa tinggi dengan tekstur nasi yang pera (Juliano, 1990 dalam Suprihatno dkk., 2009; Allidawati dan Bambang, 1989). 
Jainudin dkk: Potensi Kuantitatif dan Kualitatif 10 Galur Unggul Baru Padi Jenis Pandan Wangi ...

Tabel 1. Rata-rata bobot 1000 butir gabah, hasil gabah tiap rumpun, hasil gabah tiap hektar, kadar amilosa, dan amilopektin 15 galur padi baru rakitan Polinela

\begin{tabular}{lccc}
\hline \multirow{2}{*}{ Kode Galur } & Hasil Gabah/Ha & Amilosa & Amilopektin \\
\cline { 2 - 4 } & $\mathbf{( k g )}$ & $\boldsymbol{( \% )}$ & $\mathbf{( \% )}$ \\
\hline B (P.W xGlr) & $7478.7 \mathrm{ab}$ & $20.2 \mathrm{e}$ & $46.5 \mathrm{~d}$ \\
C (IR-64 xCgls) & $6801.2 \mathrm{~b}$ & $18.3 \mathrm{~g}$ & $48.1 \mathrm{c}$ \\
D(P.WxCgls) & $6921.2 \mathrm{~b}$ & $13.2 \mathrm{j}$ & $51.3 \mathrm{a}$ \\
E (P.W xGlr) & $9786.1 \mathrm{a}$ & $19.2 \mathrm{f}$ & $45.1 \mathrm{e}$ \\
G (P.WxCgls) & $7390.4 \mathrm{ab}$ & $16.1 \mathrm{i}$ & $49.6 \mathrm{~b}$ \\
H (CglsxP.W) & $7140.4 \mathrm{~b}$ & $20.5 \mathrm{~d}$ & $33.5 \mathrm{k}$ \\
I (P.WxCgls) & $7530.3 \mathrm{ab}$ & $21.0 \mathrm{c}$ & $33.6 \mathrm{k}$ \\
J (GlrxP.W) & $6473.8 \mathrm{~b}$ & $16.7 \mathrm{~h}$ & $40.9 \mathrm{f}$ \\
K (P.W x Chr) & $7522.3 \mathrm{ab}$ & $16.7 \mathrm{~h}$ & $35.4 \mathrm{i}$ \\
O (P.WxGlr) & $7437 \mathrm{ab}$ & $20.7 \mathrm{~d}$ & $36.7 \mathrm{~h}$ \\
\hline
\end{tabular}

Keterangan: Angka yang diikuti oleh huruf yang sama dalam satu kolom tidak berbeda nyata pada uji BNJ 0.05

Kesepuluh galur padi baru yang dirakit Polinela memiliki potensi kandungan amilosa yang rendah sampai sedang (Tabel 1). Kandungan amilosa yang rendah memberikan gambaran bahwa tekstur nasi ke 10 galur tersebut berkisar antara sangat pulen sampai pulen. Terdapat enam galur yang memiliki kadar amilosa rendah, yaitu galur C, D, E, G, J, dan K, sedangkan yang memiliki kandungan amilosa sedang ada empat galur yaitu galur B, H, I, dan O (Tabel 1). Variabel produksi menghasilkan nilai heritabilitas 0,50, sedangkan kandungan amilosa dan amilopektin nilai heritabilitas 0,99.

Karakter kuantitatif yang memiliki nilai heritabilitas dan kemajuan genetik tinggi dapat djadikan sebagai karakter seleksi (Widyawati dkk., 2014). Pendugaan heritabilitas perlu dilakukan supaya seleksi dapat berjalan efektif. Nilai heritabilitas $\left(h^{2}\right)$ merupakan rasio varian genotipe $\left(\sigma_{g}^{2}\right)$ terhadap varian fenotipe $\left(\sigma^{2}\right)$ șluatu karakter (Fehr, 1987). Selain itu nilai heritabilitas juga merupakan suatu indikasi tingkat kehomozigotan gen-gen pengendali karakter tersebut. Nilai duga heritabilitas yang rendah mengindikasikan bahwa karakter tersebut merupakan karakter kuantitatif yang dikendalikan oleh banyak gen. Sebaliknya nilai duga heritabilitas yang tinggi menunjukkan bahwa suatu karakter merupakan karakter kualitatif yang dikendalikan oleh sedikit gen-gen mayor. Menurut Stanfield (1983) dalam Alia, dkk. (2004), nilai heritabilitas diklasifikasikan kedalam tiga katagori, yaitu tinggi $\left(0.5 \leq h^{2}\right)$, sedang $\left(0.2 \leq h^{2}<0.5\right)$, dan rendah $\left(h^{2}<0.2\right)$. Peubah yang menunjukkan nilai heritabilitas yang tinggi yaitu peubah hasil gabah tiap hektar, kandungan amilosa, dan kandungn amilopektin yaitu lebih besar dari 50\% (Tabel 2). Ini menunjukkan bahwa peubah-peubah tersebut lebih dipengaruhi oleh genetik, sehingga karakter tersebut bisa diturunkan.

Tabel 2. Pendugaan ragam genetik dan heritabilitas

\begin{tabular}{lccc}
\hline Peubah & Ragam Genetik & Heritabilitas & KKg $(\%)$ \\
\hline Hasil Gabah/Ha & $736404 \pm 17474^{*}$ & $0.50 \pm 0.12 *$ & 0.12 \\
Amilosa & $6.278 \pm 1.110^{*}$ & $0.99 \pm 0.17 *$ & 0.13 \\
Amilopektin & $42.47 \pm 7.509 *$ & $0.99 \pm 0.17 *$ & 0.16 \\
\hline
\end{tabular}

$*$ = ragam genetik dan heritabilitas berbeda dari 0 
Nilai heritabilitas yang tinggi ( $>50 \%)$ menunjukkan pengaruh lingkungan terhadap sifat yang diwariskan kecil, artinya kemungkinan sifat ini dapat diturunkan sangat tinggi, karena sumbangan faktor genetik terhadap keragaman total besar (Asadi dkk., 2003).

Warna nasi yang telah masak (tanak) berbeda-beda tergantung dari jenis beras yang digunakan. Pada umumnya, warna nasi adalah putih bila beras yang digunakan berwarna putih. Beras akan menghasilkan warna nasi yang serupa dengan warna berasnya. Kandungan amilosa yang rendah pada pati beras akan menghasilkan nasi yang cenderung lebih transparan dan lengket. Beras yang mengandung kadar amilosa sekitar 12-15\% nasinya lebih lengket daripada nasi yang kadar amilosanya sekitar 20\%. Pada umumnya, beras dengan kadar amilosa lebih dari 24\% akan menghasilkan nasi yang pera (tidak lekat, keras, dan mudah terpisah-pisah).

Hasil uji secara organoleptik dengan menggunakan 10 panelis, diperoleh gambaran kualitas nasi dari setiap galur padi baru rakitan Polinela. Semua galur memiliki tekstur nasi yang lunak (pulen), warna nasi yang putih cerah serta aroma yang bervariasi, yaitu agak wangi (aroma harum atau wangi yang sedang), dan memiliki aroma yang harum atau wangi. Galur yang memiliki aroma harum adalah galur E, galur G, dan galur I, sedangkan galur B, F, H, J, K, dan O, memiliki aroma nasi yang agak wangi (aroma wangi yang sedang).

\section{KESIMPULAN}

1) Galur padi baru rakitan Polinela memiliki kisaran potensi hasil gabah kering giling (GKG) antara 6,47- 9,79 ton/ha.

2) Ke 10 galur padi rakitan Polinela memiliki potensi kandungan amilosa yang rendah sampai sedang, memiliki tekstur nasi sangat pulen sampai pulen. Galur yang memiliki kadar amilosa rendah, yaitu galur C, D, E, G, J, dan K dengan tekstur nasi sangat pulen. Galur yang memiliki kandungan amilosa sedang adalah $\mathrm{B}, \mathrm{H}, \mathrm{I}$, dan $\mathrm{O}$ dengan tekstur nasi yang pulen, aroma agak wangi sampai wangi.

\section{DAFTAR PUSTAKA}

Abdullah, B. 2009. Perakitan dan Pengembangan Varietas Padi Tipe Baru. Balai Besar Penelitian Tanaman Padi. Badan Penelitian dan Pengembangan Pertanian. Padi Buku 2: 67 - 89.

Alia, Y, A. Baihaki, N. Hermiati, dan Y. Yuwariah. 2004. Pola pewarisan karakter jumlah berkas pembuluh kedelai. Zuriat.15:24-30.

Allidawati dan Bambang. 1989. Analisis Kadar Amilosa dalam Beras. http://beraskarawang. wordpress.com/2010/01/07/analisis-kadar-amilosa-dalam-beras/\#respond.

Asadi, Soemartono, M. Woerjono, dan Jumanto. 2003. Kendali genetik ketahanan kedelai terhadap penyakit virus kerdil (Soybean Stunt Virus). Zuriat, 14:1-11.

Badan Pusat Statistik. 2015. Produksi Padi, Jagung, dan Kedelai. Angka Ramalan I Tahun 2015. Berita Resmi Statistik No.62/07/Th.XVIII, 1 Juli 2015.

Fehr, W.R. 1987. Principles of cultivar depelopment.Vol I. Theory ad Technickue.McMillan Publ.Co.

Kartahadimaja, J. dan Syuriani, E.E. 2014. Laporan Penelitian. Politeknik Negeri Lampung. Tidak dipublikasikan. 
Jainudin dkk: Potensi Kuantitatif dan Kualitatif 10 Galur Unggul Baru Padi Jenis Pandan Wangi ...

Suryana, A., S. Mardianto, K. Kariyasa, dan I.P. Wardana. 2009. Kedudukan Padi Dalam Perekonomian Indonesia. Balai Besar Penelitian Tanaman Padi Badan Penelitian dan Pengembangan Pertanian.

Suprihatno, B., Daradjat, A.A., Satoto, Baehaki, Widiarta, IN., Setyono, A., Indrasari, S.D.,dan Lesmana, O. 2009. Deskripsi Varietas Padi. Balai Besar Penelitian Tanaman Padi Badan Penelitian dan Pengembangan Pertanian Departemen Pertanian.

Widyawati, Z., I. Yulianah dan Respatijarti. 2014. "Heritabilitas dan Kemajuan Genetik Harapan Populasi F2 Pada Tanaman Cabai Besar (Capsicum annum L.)” Jurnal Produksi Tanaman, Volume 2, Nomor 3, April 2013: 247-252. 